\title{
PENGARUH PSAK NO. 1 TENTANG PENYAJIAN LAPORAN CASH FLOW \\ DAN CAPITAL EXPENDITURE TERHADAP FIRM VALUE \\ PADA PERUSAHAAN YANG BERGERAK DI BIDANG CONSUMER GOOD \\ YANG TERDAFTAR DI JAKARTA ISLAMIC INDEX PERIODE 2010-2019
}

\author{
Gina Sakinah, Ade Ponirah \\ UIN Sunan Gunung Djati Bandung \\ Email: ginasakinah1004@gmail.com; adeponirah@gmail.com
}

\begin{abstract}
Financial statements are prepared and presented to be submitted to those who need them. Of course, in this presentation must be in accordance with the existing provisions that are stipulated in PSAK No. 1 concerning the presentation of financial statements. Firm Value has an important role because it will form an image for the company, firm value is created by the contribution of other factors. Operation Cash Flow informs cash inflows and cash outflows from a company. Capital Expenditure as a reserve fund to support the expansion of the company or the improvement of assets. This research uses descriptive methods and quantitative approaches using secondary data supported by literature and documentation studies. The results showed that Operation Cash Flow partially has a positive and significant effect on Firm Value as well as Capital Expenditure has a positive and significant effect on Firm Value. Simultaneously both free variables can contribute and are able to significantly affect firm value.
\end{abstract}

Keywords: Operation Cash Flow, Capital Expenditure, Firm Value

\begin{abstract}
ABSTRAK
Laporan keuangan disusun dan disajikan untuk disampaikan kepada pihak-pihak yang membutuhkannya. Tentunya dalam penyajian ini harus sesuai dengan ketentuan yang ada yaitu diatur pada PSAK Nomor 1 mengenai penyajian laporan keuangan. Firm Value mempunyai peran penting karena akan membentuk citra bagi perusahaan, firm value tercipta dengan adanya kontribusi dari faktor lain. Operation Cash Flow menginformasikan arus kas masuk dan kas keluar dari suatu perusahaan. Capital Expenditure sebagai dana cadangan untuk mendukung adanya ekpansi perusahan atau pembenahan aktiva. Penelitian ini menggunakan metode deskriptif dan pendekatan kuantitatif menggunakan data sekunder didukung dengan studi kepustakaan dan dokumentasi. Hasil penelitian menunjukkan secara parsial Operation Cash Flow berpengaruh positif dan signifikan terhadap Firm Value begitu pun dengan Capital Expenditure berpengaruh positif dan signifikan terhadap Firm Value. Secara simultan kedua variabel bebas dapat berkontribusi dan mampu mempengaruhi secara signifikan Firm Value.
\end{abstract}

Kata Kunci: Operation Cash Flow, Capital Expenditure, Firm Value 


\section{PENDAHULUAN}

Perusahaan merupakan pihak yang dipercaya oleh beberapa stake holder untuk menjalankan sebuah bisnis. Baik itu bisnis yang bergerak di bidang jasa atau pun barang. Mampu bersaing dengan perusahaan yang lain di tengah semakin ketatnya kompetisi. Maka kerjasama antara kedua belah pihak harus terus terjalin, karena masing-masing mempunyai peran yang sangat penting. Perusahaan sebagai bagian dari pihak yang menjalankan usaha harus memberikan kepercayaan penuh kepada para stake holder, salah satunya terus memberikan informasi mengenai kinerja keuangan melalui laporan keuangan perusahaan secara transparan. Karena informasi ini berguna untuk banyak pihak mulai dari mitra bisnis, investor, karyawan, pemerintah dan pihak lainnya.

Laporan keuangan suatu perusahaan sangat dibutuhkan, karena akan menginformasikan seputar arus masuk dan arus keluar keuangan perusahaan. Berguna untuk mengevaluasi kinerja perusahaan, kinerja investasi, kinerja aktivitas operasi, serta aktivitas pendanaan. Laporan keuangan berisi ringkasan dari seluruh aktivitas keuangan yang secara ringkas melalui proses pencatatan transaksi keuangan selama kurun waktu terntu (Riswan \& Kesuma, 2005). Maka dalam proses pengambilan keputusan mengacu kepada laporan keuangan, karena dapat memprediksi, membandingkan dan menilai dam-ak dari keuangan dengan keputusan yang akan diambil sesuai dengan situasi ekonomi saat ini.

Dalam PSAK No. 1 mengenai penyajian laporan keuangan mengatur persyaratan mengenai penyajian laporan keuangan, struktur laporan keuangan dan persyaratan minimal isi laporan keuangan. Terdiri dari beberapa komponen laporan keuangan lengkap mulai dari laporan posisi keuangan pada akhir periode sampai dengan laporan posisi keuangan pada awal peridoe. Maka pihak entitas dalam penyusunan laporan keuangan harus sesuai dengan SAK (IAI, 2021). Erat kaitannya dalam membaca laporan keuangan para stake holder menyoroti firm value atau sering dikenal dengan nilai perusahaan. Karena dapat menggambarkan kebehasilan perusahaan dalam menjalankan usahanya.

Firm Value dapat menentukan kesejahteraan para investor karena pada dasarnya pembagian dividen berpatok kepada seberapa besar firm value yang dimiliki (Brigham \& Gapenski, 1996). Upaya yang dilakukan yaitu meningkatkan nilai pasar atas harga saham perusahaan. Hal ini hanya garis besarnya saja karena pada dasarnya bergantung kepada keputusan-keputusan dibidang keuangan. Firm Value yang bersifat positif akan mempermudah untuk memenuhi kepentingan-kepentingan yang bersangkutan sebaliknya jika bersifat negatif akan mengambat disegala akvitas operasionalnya sehingga akan menyulitkan pihak yang berkepentingan (Pabundu, 2012).

Pada dasarnya peningkatan dan penurunan Firm Value adanya kontribusi dari faktor lain salah satunya yaitu Operation Cash Flow dan Capital Expenditure. Operation Cash Flow bagian yang sangat penting dalam laporan arus kas karena menyajikan selisih kas masuk dengan kas keluar yang berasal dari aktivitas operasi perusahaan (Yulius \& Tian, 2013). Variabel ini merupakan penghasil utama pendapatan yang berasal dari semua kas yang berasal dari setiap transaksi atau kejadian bagian dari penentu laba bersih, meliputi penjualan barang dagangan, pembayaran kas keluar, pembelian baahan baku dan gaji karyawan perusahaan. Kas berperan penting dalam operasional perusahaan sehinggal menjadi aspek yang menjadi perhatian penuh para 
pihak terkhusus investor, karena akan informasi arus kas akan berdampak pada volume perdagangan saham serta akan mempengaruhi fluktuasi harga saham (Suwaldiman \& Diwasari, 2018).

Capiral Expenditure sering digunakan oleh para analisator sebagai suatu sinyal untuk memprediksi kinerja keuangan dimasa yang akan datang mempunyai peranan penting mengenai corporate finance (Li, 2004). Direalisasikan dalam beberapa kegiatan seperti pengembangan perusahaan, eksplorasi perusahaan serta jika memungkinkan adanya biaya produksi yang direncanakan perusahaan seperti pembenahan sistem distribusi, memperbaiki sarana produksi dan pengembangan produk (Sartono, 2001). Capiral Expenditure dapat memperkecil risiko ketidakpastian proses produksi, jika ada kendala maka dapat mengatasi dengan cepat dengan cara modernisasi atau membeli aktiva baru. Maka tidak terjadi kendala produksi, operional tetap berjalan lancar maka kinerja perusahaan terus meningkat. Peningkatan ini akan berdampak kepada firm value karena harga saham perusahaan meningkat juga (Mispiyanti, 2020).

Maka dari itu, artikel ini bertujuan untuk menganalisis pengaruh Operation Cach Flow dan Capiral Expenditure terhadap Firm Value. Menggunakan objek perusahaan yang bergerak di bidang consumer good terdaftar di Jakarta Islamic Index (JII) yaitu PT. Indofood CBP Sukses Makmur Tbk. data penelitian berasal dari laporan keuangan periode 2010 hingga 2019 yang diunduh dari web resmi www.indofoodcbp.com. Penelitian sebelumnya masih mempunyai konsistensi terkait pengaruh variabel tersebut.

\section{Metode}

Pada penelitian ini diuji menggunakan metode deskriptif dibarengi dengan pende katan kuantitif yang menguraikan secara terstruktur dari seluruh fakta serta hubungannya dengan variabel-variabel yaitu menganalisis data numerik menggunakan uji statistik. Penelitian ini menggunakan data sekunder yang didapatkan dari laporan keuangan PT. Indofood CBP Sukses Makmur, Tbk mulai dari tahun 2010 hingga tahun 2019 didapatkan dari web resmi www.indofoodcbp.com. Metode analisis data diolah secara statistik dan secara kuantitatif dengan bantuan perangkat lunak SPSS. Dalam teknik penghitungan yang digunakan adalah analisis regresi, uji hipotesis, dan uji...kekuatan hubungan dengan $\mathrm{R}$ Square dan pearson producr moment.

\section{HASIL DAN PEMBAHASAN}

Dalam penelitian dilakukannya analisis pengaruh Operation Cash Flow dan Capital Expenditure terhadap Firm Value PT. Indofood CBP Sukses Makmur Tbk, periode 2010-2019 dengan cara parsial maupun simultan.

\section{Pengaruh Operation Cash Flow terhadap Firm Value PT. Indofood CBP Sukses Makmur, Tbk periode 2010-2019}

Operation Cash Flow termasuk dalam indikator kemampuan perusahaan untuk melunasi pinjaman, melakukan pembayaran dividen serta melakukan investasi baru tanpa menggunakan pendanaan dari pihak luar. Operation Cash Flow berguna untuk pihak investor karena dapat menilai kemampuan perusahaan dari segi arus kas yang berasal dari operasional perusahaan. Jika Operation Cash Flow termasuk dalam kategori positif yang menandakan adanya kemampuan untuk menhasilkan kas dari kegiatan operasonal perusahaan serta mampu juga untuk berinvestasi, sebaliknya jika termasuk dalam kategori negatif perusahaan tidak mampu 
menghasilkan arus kas serta mengandalkan pendanan dari luar untuk menunjang perusahaan (Winarno, 2012).
Berikut hasil penelitian, kesesuaian antara teori adan hasil pengujian yang telah dilakukan:

Tabel 1 Hasil Regresi Linear dan Uji t Pengaruh Operation Cash Flow terhadap Firm Value PT. Indofood CBP Sukses Makmur, Tbk periode 2010-2019

Coefficients ${ }^{\mathrm{a}}$

\begin{tabular}{|c|c|c|c|c|c|c|}
\hline & \multirow[b]{2}{*}{ Model } & \multicolumn{2}{|c|}{ Unstandardized Coefficients } & $\begin{array}{l}\text { Standardized } \\
\text { Coefficients }\end{array}$ & \multirow[b]{2}{*}{$\mathrm{T}$} & \multirow[b]{2}{*}{ Sig. } \\
\hline & & B & Std. Error & Beta & & \\
\hline \multirow[t]{2}{*}{1} & (Constant) & -1.623 & 3.576 & & -.454 & .662 \\
\hline & OCF & 1.487 & .331 & .846 & 4.495 & .002 \\
\hline
\end{tabular}

a. Dependent Variabel : Firm Value

Sumber: output SPSS versi 22.0

Merujuk pada tabel diatas, didapatkan model persamaan sebagai berikut:

Firm Value $=-1,623+1,487$ Operation Cash Flow

Sesuai dengan model persamaan yang telah disajikan mengandung arti bahwa ketika nilai variabel independen (Operation Cash Flow) bernilai nol, maka nilai variabel dependen (Firm Value) akan berubah menjadi -1,623. Apabila variabel independen (Operation Cash Flow) berubah sebesar 1 (satu) maka akan mengubah pada besarnya variabel dependen (Firm Value) menjadi 1,487. Persamaan ini mempunyai arah positif antara Operation Cash Flow terhadap Firm Value.

Hasil pengujian hipotesis dengan menggunakan $t$-statistic menunjukan pengaruh signifikan karena $t$ hitung $>t$ tabel yaiitu 4,495 $>$ 2,365 didukung dengan nilai signifikansi $0,002>0,05$. Maka dari pengujian ini dapat ditarik kesimpulan bahwa Firm Value dipengaruhi oleh Operation Cash Flow secara signifikan. Selanjutnya dilakukannya pengujian kekuatan hubungan dan kontribusi Operation Cash Flow terhadap Firm Value dengan hasil sebagai berikut:

Tabel 2 Uji Korelasi dan Koefisien Determinasi Operation Cash Flow terhadap Firm Value PT. Indofood CBP Sukses Makmur, Tbk periode 2010-2019

Model Summary

\begin{tabular}{|c|c|c|c|c|}
\hline Model & $\mathrm{R}$ & R Square & $\begin{array}{l}\text { Adjusted } \mathrm{R} \\
\text { Square }\end{array}$ & $\begin{array}{c}\text { Std. Error of the } \\
\text { Estimate }\end{array}$ \\
\hline 1 & $.846^{\mathrm{a}}$ & .716 & .681 & 4.292486 \\
\hline
\end{tabular}

a. Predictors: (Constant), Operation Cash Flow

Sumber: output SPSS versi 22.0

Merujuk pada hasil pengujian diatas, menerangkan besarnya hubungan Operation Cash Flow terhadap Firm Value sebesar 0,846 termasuk dalam kategori kuat. Dan hasil $\mathrm{R}$ Square $\left(r^{2}\right)$ sebesar 0,716 atau sama dengan 71,6\%. Memiliki arti bahwa Firm Value hanya 
dipengaruhi Operation Cash Flow sebesar 71,6\% sisanya $28,4 \%$ dipengaruhi oleh faktor lain.

Hasil penelitian ini seusai dengan penelitian yang dialakukan oleh Lestari dan Sari bahwa Arus Kas berpengaruh terhadap Nilai Perusahaan (Lestari \& Sari, 2015). Namun berbanding terbalik dengan hasil penelitain yang dilakukan oleh Suwaldiman dan Diwasasri bahwa Arus Kas Operasi tidak berpengaruh signifikan terhadap Nilai Perusahaan (Suwaldiman \& Diwasari, 2018). Implikasinya ialah mayoritas investor PT. Indofood CBP Sukses Makmur, Tbk sangat memperhatikan Operation Cash Flow karena menjadi bahan pertimbangan kinerja perusahan dalam kurun waktu tertentu. Karena hal ini akan mempengaruhi terhadap kebijakan dalam Rapat Umum Pemegang Saham (RUPS) mengenai nominal pembagian dividen. Serta berkaitan dengan tim manajemen untuk memprediksi jika ke depannya akan dilakukan ekspansi perusahaan agar sesuai dengan tujuan perusahaan.

\section{Pengaruh Capital Expenditure terhadap Firm} Value PT. Indofood CBP Sukses Makmur

Investor lebih tertarik pada perusahaan yang memiliki investasi modal karena dalam pengambilan keputusan-keputusan investasi akan mendatangkan keuntungan yang lebih besar di masa yang akan datang (Braeley et al., 2007). Keputusan investasi yang menggunakan Capital Expenditure akan memberikan sinyal positif dan pertumbuhan perusahaan berjalan baik kemudian investor akan merespon dengan baik (Achmad \& Amanah, 2014). Hal ini sesuai dengan signaling theory yang menyatakan bahwa sinyal positif bagi investor yaitu keputusan investasi. Dengan keputusan investasi ini diharapkan memberikan dampak baik terhadap pertumbuhan perusahaan serta mampu bersaing karea peningkatan pertumbuhan perusahaan menggambarkan kinerja perusahaan yang baik. Maka secara beriringan nilai perusahaan ikut meningkat. Dengan mengoptimalkan modal juga arus kas akan memberikan kelnacaran dalam operasional perusahaan (Sofiamira \& Haryono, 2017).

Berikut hasil penelitian yang telah dilakukan, dengan adanya keseuaian antara teori dengan hasil pengujian yang telah dilakukan:

Tabel 3 Hasil Regresi Linear dan Uji t Pengaruh Capital Expenditure terhadap Firm Value PT. Indofood CBP Sukses Makmur, Tbk periode 2010-2019

Coefficients $^{a}$

\begin{tabular}{|c|c|c|c|c|c|}
\hline \multirow{2}{*}{ Model } & \multicolumn{2}{|c|}{$\begin{array}{c}\text { Unstandardized } \\
\text { Coefficients }\end{array}$} & \multicolumn{1}{c|}{$\begin{array}{c}\text { Standardized } \\
\text { Coefficients }\end{array}$} & & \\
\cline { 2 - 5 } & $\mathrm{B}$ & $\begin{array}{c}\text { Std. } \\
\text { Error }\end{array}$ & Beta & $\mathrm{T}$ & Sig. \\
\hline (Constant) & 4.696 & 4.138 & & 1.135 & .289 \\
CE & .855 & .364 & .639 & 2.377 & .047 \\
\hline
\end{tabular}

a. Dependent Variabel : Firm Value

Sumber: output SPSS versi 22.0

Merujuk pada tabel diatas, didapatkan model persamaan sebagai berikut: 


\section{Firm Value $=4,696+0,855$ Capital Expenditure}

Sesuai dengan model persamaan yang telah disajikan mengandung arti bahwa ketika nilai variabel independen (Capital Expenditure) bernilai nol, maka nilai variabel dependen (Firm Value) akan berubah menjadi 4,969. Apabila variabel independen (Capital Expenditure) berubah sebesar 1 (satu) maka akan merubah pada besarnya variabel dependen (Firm Value) menjadi 1,487. Persamaan ini mempunyai arah positif antara Capital Expenditure terhadap Firm Value.
Hasil pengujian hipotesis dengan menggunakan t-statistic menunjukan pengaruh signifikan karena $t$ hitung $>t$ tabel yaiitu 2,377 > 2,365 didukung dengan nilai signifikansi 0,047 >0,05. Maka dari pengujian ini dapat ditarik kesimpulan bahwa Firm Value dipengaruhi oleh Capital Expenditure secara signifikan.

Selanjutnya dilakukannya pengujian kekuatan hubungan dan kontribusi Capital Expenditure terhadap Firm Value dengan hasil sebagai berikut:

Tabel 4 Uji Korelasi dan Koefisien Determinasi Capital Expenditure terhadap Firm Value PT. Indofood CBP Sukses Makmur, Tbk periode 2010-2019

\begin{tabular}{|c|c|c|c|c|}
\hline \multirow{2}{*}{ Model } & $\mathrm{R}$ & R Square & $\begin{array}{l}\text { Adjusted R } \\
\text { Square }\end{array}$ & $\begin{array}{c}\text { Std. Error of the } \\
\text { Estimate }\end{array}$ \\
\hline 1 & $.639^{\mathrm{a}}$ & .408 & .334 & 6.202210 \\
\hline
\end{tabular}

Merujuk pada hasil pengujian diatas, menerangkan besarnya hubungan Capital Expenditure terhadap Firm Value sebesar 0,693 termasuk dalam kategori sedang. Dan hasil $\mathrm{R}$ Square $\left(\mathrm{r}^{2}\right)$ sebesar 0,408 atau sama dengan 40,8\%. Memiliki arti bahwa Firm Value hanya di pengaruhi oleh Capital Expenditure sebesar $40,8 \%$ sisanya $59,2 \%$ dipengaruhi oleh faktor lain.

Hasil penelitian ini sejalan dengan penelitian yang dilakukan oleh Mispiyanti bahwa Capital Expenditure mempunyai pengaruh positif terhadap Firm Value (Mispiyanti, 2020). Implikasinya bahwa pihak manajemen PT. Indofood CBP Sukses Makmur, Tbk mengalokasikan Capital Expenditure dengan tepat yaitu dialokasikan untuk penambahan, perbaikan dan peningkatan kualitas aktiva tetap yang mempunyai manfaat dengan jangka panjang. Dengan adanya hal ini akan menarik investor baru maka akan menghasilkan laba yang cukup tinggi. Keputusan ini memberikan dampak positif terhadap pertumbuhan ekonomi. Karena jika aktiva tetap dalam keadaan baik maka proses produksi pun akan berjalan lancar sehingga tidak ada kendala, operasional perusahaan terus meningkat. Dengan reputasi PT. Indofood CBP Sukses Makmur, Tbk yang baik serta produk yang dijual sudah di kenal banyak orang disertai dengan ketepatan pihak manajemen dalam pengalokasian modal maka hal ini yang melandasi kepercayaan investor karena nilai perusahaan baik sehingga harga saham akan terus naik.

\section{Pengaruh Operation Cash Flow dan Capital} Expenditure terhadap Firm Value PT. Indofood CBP Sukses Makmur

Firm Value didefinsikan sebagai nilai pasar. Nilai pasar terbentuk karena adanya 
transaksi antara pembeli dan penjual. Nilai pasar ini dibentuk melalui indikator nilai pasar saham yang menjadi cerminan nilai aset perusahan sesu ngguhnya dipengaruhi oleh peluang-peluang investasi. Sinyal positif muncul ketika adanya peluang investasi karena akan mempengaruhi pertumbuhan perusahaan di masa yang akan datang hal ini akan meningkatkan nilai perusahaan (Kurnia, 2017).

Berikut hasil penelitian yang telah dilakukan, dengan adanya keseuaian antara teori dengan hasil pengujian yang telah dilakukan:

Tabel 5 Hasil Uji Simultan Pengaruh Operation Cash Flow dan Capital Expenditure terhadap Firm Value PT. Indofood CBP Sukses Makmur, Tbk periode 2010-2019

ANOVA $^{a}$

\begin{tabular}{|c|c|c|c|c|c|}
\hline Model & $\begin{array}{l}\text { Sum of } \\
\text { Squares }\end{array}$ & $\mathrm{df}$ & Mean Square & $\mathrm{F}$ & Sig. \\
\hline $1 \underset{\text { on }}{\text { Regressi }}$ & 415.726 & 2 & 207.863 & 14.000 & $.004^{\mathrm{b}}$ \\
\hline $\begin{array}{ll} & \text { Residua } \\
1 & \end{array}$ & 103.933 & 7 & 14.848 & & \\
\hline Total & 519.659 & 9 & & & \\
\hline
\end{tabular}

a. Dependent Variabel : Firm Value

b. Predictors: (Constant), Operation Cash Flow, Capital Expenditure

Sumber: Output SPSS versi 22

Dari tabel yang disajikan diatas, terdapat hasil uji simultan dengan hasil Operation Cash Flow dan Capital Expenditure berpengauh signifikan terhadap Firm Value karena memenuhi syarat yaitu $\mathrm{F}$ hitung $>\mathrm{F}$ tabel 14,000 > 4,74 dengan tingkat signifikansi 0,004.
Untuk menguji kekuatan hubungan dan kontribusi pengaruh Operation Cash Flow dan Capital Expenditure terhadap Firm Value sebagai berikut:

Tabel 5 Hasil Uji Korelasi dan Determinasi Operation Cash Flow dan Capital Expenditure terhadap Firm Value PT. Indofood CBP Sukses Makmur, Tbk periode 2010-2019 Model Summary

\begin{tabular}{|c|c|c|c|c|}
\hline Model & $\mathrm{R}$ & R Square & $\begin{array}{l}\text { Adjusted R } \\
\text { Square }\end{array}$ & $\begin{array}{c}\text { Std. Error of the } \\
\text { Estimate }\end{array}$ \\
\hline 1 & $.894^{\mathrm{a}}$ & .800 & .743 & 3.853256 \\
\hline
\end{tabular}

Merujuk pada hasil pengujian diatas, menerangkan besarnya hubungan Capital Expenditure terhadap Firm Value sebesar 0,894 termasuk dalam kategori kuat. Dan hasil $\mathrm{R}$
Square $\left(\mathrm{r}^{2}\right)$ sebesar 0,800 atau sama dengan $80 \%$. Memiliki arti bahwa Firm Value hanya di pengaruhi oleh Operation Cash Flow dan Capital 
Expenditure sebesar $80 \%$ sisanya $20 \%$ dipengaruhi oleh faktor lain.

\section{SIMPULAN}

Pada bagian akhir penelitian memuat hasil akhir, pertama Operation Cash Flow dapat mempengaruhi Firm Value secara parsial. Kedua, Capital Expenditure dapat mempengaruhi Firm Value. Ketiga, kedua variabel mampu mempengaruhi Firm Value dengan kontribusi sebesar $80 \%$. Implikasi dalam penelitian ini entitas harus dapat menjaga nilai perusahaan. Terciptanya nilai perusahaan yang baik didukung oleh faktor lain salah satu diantaranya yaitu menjaga kestabilan nilai
Operation Cash Flow dan Capital Expenditure. Karena perlu disadari pengelolaan kas merupakan hal yang sangat penting bagi perusahaan, serta informasi ini dapat menjadi landasan bagi para stake holder bagaimana kinerja perusahaan berjalan. Serta bagaimana perusahaan mengelola modal investasi untuk keperluan produksi yang dialokasikan pada kebutuhan produski. Nyatanya pihak manajemen PT. Indofood CBP Sukses Makmur, Tbk dapat mengelolanya dengan baik sehingga tetap dapat menjaga kepercayaan investor tentunya dalam penyajian laporan keuangan ini sesuai dengan ketentuan PSAK no 1 mengenai penyajian laporan keuangan.

\section{REFERENSI}

Achmad, S. ., \& Amanah, L. (2014). Pengaruh Keputusan Investasi, Keputusan Pendanaan, Kebijakan Dividen dan Kinerja Keuangan terhadap Nilai Perusahaan. JUrnal Ilmu Dan Riset Akuntansi, 3(9), 1-15.

Braeley, R. A., Myers, S. C., \& Marcus, A. . (2007). Dasar-dasar Manajemen Keuangan Perusahaan. Erlangga.

Brigham, E. F., \& Gapenski, L. C. (1996). Intermediate Financial Management. The Dryden Press.

IAI. (2021). Standar Akuntansi Keuangan. Ikatan Akuntan Indonesia. http://iaiglobal.or.id/v03/ standar-akuntansi-keuangan/pernyataan-sak-7-psak-1-penyajian-laporan-keuangan

Kurnia, D. (2017). Analisis Signifikansi Leverage dan Kebijakan Dividen terhadap Nilai Perusahaan. Denny, 4, 12-21.

Lestari, R. M. E., \& Sari, P. P. (2015). Komparasi Pengaruh Arus Kas terhadap Nilai Perusahaan Antara PT Hero Supermarket Tbk dengan PT Matahari Putra Prima Tbk. Jurnal Ilmiah Akuntansi Fakultas Ekonomi, 1(1), 33-37.

Li, D. (2004). The Implications of Capital Investments for Future Profitability and Stock Returns - an Overinvestment Perspective Haas School of Business. University of California.

Mispiyanti. (2020). Pengaruh Struktur Modal, Capital Expenditure, Profitabilitas Dan Kebijakan Dividen Terhadap Nilai Perusahaan Pada Perusahaan BUMN Indonesia. Jurnal Akuntansi Dan Pajak, 20(2), 133-144. https://doi.org/10.29040/jap.v20i2.636

Pabundu, T. (2012). Budaya Organisasi dan Peningkatan Kinerja Perusahaan. Bumi Aksara.

Riswan, \& Kesuma, Y. F. (2005). ANALISIS LAPORAN KEUANGAN SEBAGAI DASAR DALAM PENILAIAN KINERJA KEUANGAN PT. BUDI SATRIA WAHANA MOTOR 
Riswan. NASPA Journal, 5(1), 94-121.

Sartono, A. (2001). Manajemen Keuangan: Teori dan Aplikasi Edisi Ke Empat. Badan Penerbitan Fakultas Ekonomi UGM.

Sofiamira, N. A., \& Haryono, N. A. (2017). Capital Expenditure, Leverage, Good Corporate Governance, Corporate Social Responsibility: Pengaruhnya Terhadap Nilai Perusahaan. Jurnal Ekonomi Dan Bisnis, 20(2), 191. https://doi.org/10.24914/jeb.v20i2.691

Suwaldiman, \& Diwasari, P. (2018). Pengaruh Free Cash Flow, Operating Cash Flow, dan Dividend Payout Ratio Terhadap Nilai Perusahaan. ULTIMA Accounting, 10(1), 52-65. https://doi.org/10.31937/akuntansi.v10i1.845

Winarno, D. (2012). Pengaruh Profitabilitas, Struktur Modal, dan Operating Cash Flow Terhadap Return Saham (Perusahaan Property dan Real Estate yang Terdaftar di BEI). Fakultas Ekonomi, 1-27.

Yulius, \& Tian, Y. (2013). Pengaruh Earning, Operating Cash Flow dan Asset Growth terhadap Stock Return Perusahaan yang Terdaftar Pada Index LQ 45 Untuk Periode 2009-2011. Media Riset Akuntansi, Auditing Dan Informasi, 13(1), 157-176. 
gina sakinah, ade ponirah 